\title{
HOW MARKetS WORK: THE LAWYER'S VERSION
}

\author{
W. Mark C. Weidemaier \& Mitu Gulati
}

\begin{abstract}
In this article, we combine two sources of data to shed light on the nature of transactional legal work. The first consists of stories about contracts that circulate widely among elite transactional lawyers. Surprisingly, the stories portray lawyers as ineffective market actors who are uninterested in designing superior contracts, who follow rather than lead industry standards, and who depend on governments and other outside actors to spur innovation and correct mistakes. We juxtapose these stories against a dataset of sovereign bond contracts produced by these same lawyers. While the stories suggest that lawyers do not compete or design innovative contracts, their contracts suggest the contrary. The contracts, in fact, are entirely consistent with a market narrative in which lawyers engage in substantial innovation despite constraints inherent in sovereign debt legal work. This raises a puzzle: Why would lawyers favor stories that paint them in a negative light and deny them a potent role as market actors? We conclude with some conjectures as to why this might be so.
\end{abstract}

\footnotetext{
- Faculty at the University of North Carolina School of Law and Duke University School of Law. An earlier version of this paper was presented at the conference on Socializing Economic Relationships: New Perspectives and Methods for Transnational Risk Regulation, at the Centre for Socio-Legal Studies at the University of Oxford. We thank Bettina Lange, Dania Thomas, and conference participants for comments on the article.
} 


\section{INTRODUCTION}

Lawyers are integral players in the world of international finance, and contracts are the primary tools of their trade. We focus on one group of these lawyers, those who structure loans to governments, and we explore their relationship to their primary legal product: sovereign bond contracts. Our inquiry stems from a conference on the relevance of Karl Polanyi's work to the current global financial crisis. As we write, in July 2011, fear of sovereign default in the Eurozone, and anger over bailouts given to distressed countries, have prompted intense debate over how to avoid future crises. To a significant degree, this is a debate about contracts. Eurozone politicians, for example, seem to believe that sovereign borrowers and their lenders can avert future crisis by adopting the right contract terms. In particular, they have proposed that all future sovereign bond contracts include terms called Collective Action Clauses - CACs, for short.

It may seem far-fetched to suggest that a contract term can prevent global financial crisis or make future bailouts unnecessary. (It seems so to us.) But this is not the first time CACs have been touted as the solution to such problems. Nor is it new for CACs to be the subject of intense discussion among participants in the sovereign debt markets. Stories about CACs abound, and we begin this article by exploring stories popular among sovereign debt lawyers. In the process, we reveal a tension. These lawyers occupy high-status positions in prestigious law firms, and their transactions occupy the front pages of the financial newspapers. They are quintessential market actors, and one might expect them to situate their stories within a broader market narrative that emphasizes the virtues of competition and implies that elite lawyers distinguish themselves through superior skill and ability to innovate. But in fact, sovereign debt lawyers routinely tell stories that portray them as reluctant competitors who depend on governments or other third parties to spur innovation. The stories imply that lawyers are uninterested in 
producing superior contracts, reluctant to innovate, eager to portray any changes they do make as following (as opposed to leading) industry standards, and skeptical of the market's ability to recognize or value higher-quality contracts. Many of the stories imply that sovereign debt work consists primarily of photocopying, even when the documents being copied contain mistakes.

If the stories accurately described sovereign debt legal work, they would fit the theme of this conference nicely. At a superficial level, the stories suggest that markets left to their own devices exhibit deficiencies "so great that government intervention becomes necessary" (Stiglitz, 2001, p. ii). We might use the stories, therefore, to tell a cautionary tale about the dangers of unregulated markets. Moreover, at least as his work has been extended by others, Polanyi calls attention to the fact that market activity occurs within a network of social relations and that even seemingly irrational behavior "may be quite sensible when situational constraints" are taken into account (Granovetter 1985:506). Thus, we might attempt to explain the perplexing behavior depicted by the stories - elite lawyers charging vast sums to photocopy mistakes - as a rational response to the institutional and professional context in which sovereign debt lawyers operate. We might emphasize, for example, that this context rewards high-volume, rote legal work. And we might posit that many important players in sovereign lending transactions, including bankers and government finance officials, would rather live with an imperfect contract than allow a deal to be delayed or derailed by uncertainty about the meaning of a change in contract terms.

The problem, however, is that the stories do not seem to match how lawyers behave. In the second part of the article, we use a dataset of sovereign bond contracts to explore actual contracting practices with respect to CACs. While the stories suggest that lawyers do not compete or design innovative contracts, the data on their contracts suggests the contrary. The contracts, in fact, are entirely consistent with a market narrative in which lawyers engage in 
substantial innovation despite constraints inherent in sovereign debt legal work. This raises a puzzle: Why would lawyers favor stories that paint them in a negative light and deny them a potent role as market actors? We conclude with some conjectures as to why this might be so.

\section{Collective Myths About Collective Action}

\section{Infinite Variety... At Least in Theory: An Introduction to CACs}

Sovereign issuers and bondholders face a problem common to lending relationships. If the issuer encounters financial difficulty, all parties might be better off agreeing to reduce or restructure its repayment obligations and thereby hasten its return to financial health. Yet bondholders are many and dispersed, and this results in familiar coordination problems that can block an otherwise beneficial restructuring (Sachs, 1984). Unlike corporate debt, moreover, no sovereign bankruptcy regime exists to impose restructuring terms on a recalcitrant minority of holdout creditors (Bratton, 2004; Skeel, 2003). As a result, issuers who wish to provide for the possibility of a future restructuring must turn to the institution of contract.

At least in theory, an issuer could include a wide range of restructuring-related terms in its bonds. Here, we focus on the subset of terms commonly labeled Collective Action Clauses (CACs). Reading the sovereign debt literature, and listening to the pronouncements of public officials, one sometimes gets the sense that CACs have near-magical properties. Over the past two decades they have twice been touted as the solution to global financial crisis. The first time was in the aftermath of the Tequila crisis and Asian financial crisis in the mid to late 1990s. As we have noted, the second time is now, when Eurozone public officials have placed CACs at the center of a proposed mechanism for resolving future sovereign defaults (Oakley, 2011).

CACs are intended to solve coordination problems among holders of sovereign bonds. In the absence of a sovereign bankruptcy mechanism, a financially distressed country that wants to restructure its payment obligations must obtain the assent of its bondholders. But the sheer 
number and geographic dispersion of bondholders makes it nearly impossible even to locate them all. Moreover, an effective restructuring requires a mechanism by which bondholders can make an orderly and collective decision that will bind them all. Otherwise, some bondholders may withhold their assent hoping to extract a side payment from those who favor the plan or to be paid in full if there is an Official Sector (i.e., taxpayer) bailout. And the prospect that such "holdouts" may receive a better deal may deter participation in the restructuring, or even derail it altogether.

In theory, CACs solve these problems by enabling bondholder coordination. Broadly speaking, CACs come in four varieties.

Modification Clauses: Modification clauses provide that every bondholder is bound by a change in contract terms approved by a defined percentage of the group. The clauses also establish procedures for obtaining bondholders' assent to the change, and these procedures can vary significantly. For example, one clause might require that any vote to change the issuer's payment obligations occur at a meeting at which a specified percentage of bondholders will constitute a quorum. A different clause might allow the issuer to solicit bondholders' written assent to the change. These are not trivial differences. Bonds that require a meeting, for example, create a forum in which unhappy creditors can meet and possibly organize against a restructuring proposal (Gelpern \& Gulati, 2008).

Modification clauses are recent innovations in sovereign bonds. They began to appear in the 1980s, primarily in bonds governed by English law. A typical clause allowed terms related to the issuer's payment obligations to be modified by a supermajority (usually 75 percent) vote and non-payment terms to be modified by a lesser vote. Any vote on a proposed restructuring had to occur at a physical meeting of the bondholders. Significantly, the requirements for conducting a 
meeting often operated to reduce the vote needed to approve a restructuring. Despite the supermajority requirement, in fact, holders of as little as 18.75 percent in aggregate amount of the outstanding debt could in theory approve a restructuring.

A different practice prevailed in bonds governed by New York law. These bonds allowed a majority of bondholders to approve a change to non-payment terms but required bondholders unanimously to approve changes to payment terms. Given the coordination difficulties noted above, this unanimity requirement was essentially unattainable. Beginning in 2003, however, bonds governed by New York law began to incorporate modification clauses (without the requirement of a physical meeting of the holders), and these soon became ubiquitous. The story of how New York-law bonds evolved to include modification clauses - which we recount below - occupies a central place in the modern mythology of sovereign debt.

Creditor Committee Clauses: A financially distressed issuer may wish to negotiate over the terms of a restructuring, but with whom should it negotiate? In the 19th and early 20th centuries, major capital exporting countries established representative committees to negotiate with sovereign borrowers on behalf of dispersed bondholders (Eichengreen \& Portes 1995). Creditor committee clauses seek to revive this practice by contract. A typical clause might allow bondholders to establish a committee empowered to negotiate on their behalf, specify the circumstances under which such a committee may be appointed, identify powers that may be assigned to the committee, and even require the issuer to pay the expenses of any professionals hired to assist the committee (Richards, 2010).

Trustee Clauses: A variety of administrative and ministerial tasks must be performed in connection with the issuance of sovereign bonds. The agent that performs these tasks (often a Fiscal Agent) owes duties to the borrower and not to the bondholders. Some bond contracts, 
however, provide for a trustee that owes specified duties directly to bondholders. For example, a trustee clause might empower the trustee to institute litigation against the borrower in response to a default. Because the trustee owes duties to the bondholders as a group, and not to any bondholder in particular, the presence of a trustee may offer some protection against bondholders whose self-interested behavior may harm the group (Richards, 2010).

Non-acceleration Provisions: Most sovereign bonds require the issuer to make periodic small payments to bondholders. For obvious reasons, bondholders may interpret the failure to make one of these payments as a sign of financial distress. One response to such a signal is for the bondholder to accelerate their loan - i.e., to demand full payment of the principal. Until at least the mid-1990s, sovereign bonds often allowed each bondholder to decide whether to accelerate their loan in response to the issuer's default in making a small payment. Individual creditors, however, often are quick to accelerate, in part because they fear other creditors will beat them to it and deplete the issuer's remaining assets. And in the aggregate, these individual decisions to accelerate can have disastrous consequences for the issuer's ability to meet its obligations. As a result, some modern bonds take the decision to accelerate out of the hands of individual bondholders. Instead, these bonds require acceleration to be approved by a specified percentage of bondholders (typically 25 percent). They also allow a defined percentage of bondholders (often 50 percent) to reverse the decision to accelerate.

\section{A Mistake, Compounded: The Mythology of CACs}

Sovereign bonds issued under New York and English law observed different drafting conventions before 2003. English-law bonds included modification clauses that allowed for modifications with a vote as low as 18.75 percent, while New York-law bonds required unanimous approval to change payment terms. This difference rapidly disappeared after 2003, when Mexico became the first major issuer of New York-law bonds to include CACs. Other 
issuers quickly followed suit, and modification clauses became standard in bonds issued under both laws.

Sovereign debt lawyers tell a number of stories about this evolution. These stories have circulated widely and assumed a prominent place in current and past debates about resolving global financial crises. ${ }^{1}$ We report the stories because we believe they can shed light on the work that lawyers do, although we are aware that stories do not always match reality (Mather, McEwen \& Maiman, 2001, p. 199). Indeed, one reason we find the stories interesting is that they do not match reality (Weidemaier, Scott \& Gulati, 2011). The stories purport to explain a significant evolution in modern contracting practices. They do so, first, by communicating an origin myth that locates the divergence between New York and English-law contracts in a mistake made nearly a century ago. The stories also provide an explanation for why this divergence persisted for so long. And finally, they explain how New York-law bonds finally came to adopt CACs and provide reason to believe that sovereign bonds are now largely standardized.

As we show later, these stories are largely inaccurate. Like other terms in sovereign bonds (Weidemaier, 2009; Gelpern \& Gulati, 2008), CACs exhibit a great deal more variance than the stories allow. But this does not deprive the stories of meaning. Storytelling is a common social activity. And although stories are often framed as representing a widely-shared experience (Briggs, 1996), they do not simply recount some objective reality (Bauman, 1986). Origin myths, for example, need not be viewed as empirical propositions. In a sense, their truth is unimportant; adherents to such myths view them as self-evident explanations for prevailing cultural or social

\footnotetext{
${ }^{1}$ The stories we recount circulated widely in print, but we also rely on extensive interviews with sovereign debt lawyers. Methodological and other detail on these interviews is provided in Gelpern and Gulati (2006). To a lesser extent, we also draw on stories explored in Gulati \& Scott (2011) and Weidemaier, Scott and Gulati (2011).
} 
practices (Engle, 1993; O'Barr \& Conley, 1992). For that reason, stories can provide insight into how people make sense of their everyday experience. We use these myths about the origin and evolution of CACs - and their doppelganger, the unanimity requirement - to shed light on how lawyers view their role in sovereign lending transactions.

The first story purports to explain how New York and English-law bonds adopted different drafting conventions nearly a century ago and adhered to these separate practices until 2003. It begins with a mistake.

\section{How Lawyers Learned to Stop Worrying and Love the CAC.}

As noted, bonds issued under New York and English law observed different drafting conventions until around 2003. The difference was a matter of common knowledge but engendered little discussion. Bonds issued under the different laws were, well, different. It didn't really matter why.

That began to change after a series of financial crises and defaults beginning with the Mexican Tequila crisis in the mid-1990s and culminating in Argentina's default in 2001 (Roubini \& Setser, 2004). The former resulted in a politically unpopular bailout and the latter in a lengthy and contentious restructuring. Neither outcome was desirable, and public officials felt pressured to give assurances that future defaults would be resolved quickly and without taxpayer-funded bailouts. (A similar saga unfolds in the Eurozone as we write this.) Key policy actors, including prominent economists and lawyers, identified CACs as the solution (Quarles, 2010; Eichengreen \& Mody, 2000a, 2000b; Buchheit \& Gulati, 2002). Much of the relevant debt had been issued under New York law, where the unanimity requirement made restructuring difficult. In theory, the problem could be solved by creating a mechanism to facilitate future restructurings. One possibility was to create a sovereign bankruptcy regime that could impose 
restructuring terms on bondholders. The other was to convince the New York market to emulate English drafting conventions and to adopt CACs (Eichengreen, 2003).

Many public officials favored CACs as the solution, including policy-makers within the U.S. treasury (Quarles, 2010; Gelpern \& Gulati, 2006). But there was a problem. Participants in international capital markets tend to have some faith in the market (at least the bankers, that is). And a significant part of the market for sovereign debt seemingly had voted against CACs. For years, countries had issued and investors had happily bought New York-law sovereign bonds whose payment terms could not be amended without unanimous assent. True, no one seemed to know just why these bonds required unanimity, but it was not hard to posit a rational explanation: The unanimity requirement functioned as a commitment device. Viewed ex post from the perspective of a distressed sovereign and its creditors, the requirement seems hard to justify. By exacerbating bondholder coordination problems, the requirement can delay a beneficial restructuring that will allow a genuinely distressed sovereign to resume debt service (Eichengreen, 2003). But viewed ex ante, the unanimity requirement makes more sense. By committing to an expensive and cumbersome restructuring process, issuers who adopt the requirement can send a credible signal that default is unlikely. Because lenders cannot completely verify the sovereign's intent and ability to repay at the time they make the loan, they may value that signal and agree to lend on more favorable terms (Weinschelbaum \& Wynne, 2005).

Despite these arguments in favor of current practices, public officials continued to view CACs as a substantial improvement over terms requiring unanimity. But how to convince the market to adopt them? Part of the solution was to tell a story designed to show that the unanimity requirement had no rational purpose - that it was, in fact, nothing but a historical mistake that 
had somehow persisted in modern contracts. In this story, the unanimity requirement emerged from the Trust Indenture Act (TIA) of 1939 (Quarles, 2010; Olivares-Caminal, 2009). Part of a package of Depression-era reform legislation, the TIA forbade the use of CACs in publiclyissued corporate debt (Roe, 1987). This unanimity requirement may have made sense in the context of corporate bonds, since corporate entities can always restructure their debt through bankruptcy (Skeel, 2001, p. 121-22). But without recourse to bankruptcy, sovereign issuers can only restructure their debt with creditor consent. In that context, the unanimity requirement imposes a nearly insuperable barrier to restructuring and, indeed, the TIA does not impose the requirement on sovereign bonds (Buchheit \& Gulati, 2002).

According to the story, lawyers drafting sovereign bonds began with corporate bonds as their template. They imported the unanimity requirement from these bonds, either because they mistakenly believed the TIA required them to do so or because they did not bother to read the documents they copied. In most versions, the mistake happened shortly after the TIA's enactment in 1939 (Quarles, 2010; Gray, 2003). ${ }^{2}$ But whenever the mistake occurred, it persisted, as lawyers copied the mistake over and over in new sovereign issuances. The unanimity requirement, though originally a mistake, had become boilerplate in bonds governed by New York law. By contrast, the unanimity requirement never made its way into bonds governed by English law. This was because English law, unlike U.S. law under the TIA, did not require unanimity for corporate bonds, and there was a long-standing English practice of including CACs in corporate debt. Thus, whether by design or because English lawyers, too, simply copied a corporate form, English-law sovereign debt allowed a supermajority to amend payment-related terms.

\footnotetext{
${ }^{2}$ The economic historian Barry Eichengreen (2003), however, located the split in the 1990s, when robust sovereign bond markets revived after decades of Depression-induced dormancy.
} 
This story does not flatter the lawyers. It begins by positing that the initial adopters of the unanimity requirement were ignorant of the law as it relates to sovereign debt or too lazy to read the corporate forms they used as templates. Nor is the story much kinder to modern lawyers, for it suggests they repeatedly failed to correct the mistake even though CACs would be an improvement for both country borrowers and their lenders. Under the circumstances, one might expect modern lawyers to resist the story and to offer functional explanations, along the lines we outlined above, for the unanimity requirement. The different standards, they might suggest, exist to satisfy different investor preferences. Investors who want some assurance against default buy New York-law bonds, while those who value ease of restructuring buy bonds governed by English law.

The lawyers, however, seem to like the story just fine. In a related study, Gelpern and Gulati (2006) spoke to over 100 bankers and lawyers (mostly lawyers) about the adoption of CACs in the New York market. Almost no one suggested that the unanimity requirement served any rational purpose. Indeed, a number explained that the story about the irrational origins of the unanimity provision helped overcome lawyers' ingrained resistance to changing established contracting practices. In effect, the lawyers welcomed the story as a necessary antidote to their path dependency. The implication is that, although the unanimity requirement served no purpose, lawyers never would have gotten around to removing it if the Official Sector hadn't explained that it was all just a mistake.

\section{Competition? Who Needs Competition?}

Once they had been convinced that the unanimity requirement made no sense, sovereign debt lawyers were free to adopt CACs. But what kind of CACs? The story as we have related it thus far suggests an answer: English-style CACs. If all lawyers do is copy existing forms, then they presumably would have copied recent English-law bonds. After all, many of them worked at 
global law firms with offices in London, where CACs were standard. In these firms, lawyers could have imported English-style CACs into new bonds with the push of a button. If the copying story holds true, the existing model of CACs would have migrated into bonds governed by New York law. For example, just like English-law bonds, bonds governed by New York law would require any vote to amend payment terms to take place at a meeting of bondholders.

Note, again, that this story does not assign much significance to the work that lawyers do or portray lawyers as potent market actors. A market story might describe contracts as products sold by competing law firms that may differ in quality and price. A superior CAC, for example, would somehow manage to ensure a smooth restructuring in cases of genuine financial distress without tempting issuers to default when they can afford to repay their debts. Because it is not obvious what such a CAC would look like, or that the same clause would be right for every issuer, a market story might posit that lawyers will compete to design the best clause and that the market will supply pricing information about their efforts. By 2003, in fact, a number of studies had been conducted examining whether issuers would suffer a pricing penalty by adopting CACs. The best known of these studies, two papers by Barry Eichengreen and Ashoka Mody (2000a, 2000b), suggested that CACs could affect issuers in different ways. They found that CACs lowered borrowing costs for credit-worthy issuers, who were not likely to default if they could avoid doing so, but increased borrowing costs for higher-risk issuers, for whom CACs arguably exacerbated moral hazard problems. In a market-oriented story, one would expect law firms to find data like this relevant to their efforts to design new clauses and advise issuers about what kind of CAC (if any) to adopt.

Once again, however, the lawyers describe their work primarily as copying standard forms, rather than competing to design a superior CAC. Copying stories are rampant in the 
sovereign debt world, seemingly invoked whenever lawyers encounter unexpected variance in contract terms (Weidemaier, Scott \& Gulati 2011; Gulati \& Scott, 2011). For example, most participants in the sovereign debt markets believed that Mexico's 2003 issuance was the first to include CACs in bonds governed by New York law. Only it wasn't. Two economists discovered that a number of less prominent issuers had included CACs in their New York-law bonds since as early as 1997 (Gugiatti \& Richards, 2003-2004). Was this under-the-radar innovation by a handful of small issuers? Not according to a prominent story, which attributed these early CACs to blind copying. The lawyers involved, the story explained, probably began with an Englishstyle form and thus inadvertently imported CACs into bonds governed by New York law (Gugiatti \& Richards, 2003-2004).

This is just one example. In other work, Gulati and Scott (2011) and Weidemaier, Scott, and Gulati (2011) report other instances in which sovereign debt lawyers attribute variance in bond contracts to blind copying - often of a mistake made by a junior lawyer. The assumption underlying these stories is that bond contracts are supposed to be standardized. Across a range of contexts, sovereign debt lawyers attribute variance to carelessness, not competition.

Stories about the change in New York drafting practices post-2003 are consistent with this general theme. For example, supporters of the switch to CACs in both public and private sectors invested substantial time and energy making the case that issuers could switch to the English model without suffering a pricing penalty (Gelpern \& Gulati, 2006; Gray, 2003). But from the stories sovereign debt lawyers tell, they needn't have bothered. In two separate interview studies, Gelpern and Gulati (2006) and Gulati and Scott (2011) report that sovereign debt lawyers deny that bond prices are sensitive to anything but the most dramatic changes to contract terms and routinely dismiss academic studies purporting to show the contrary. A related 
story is that investors do not wish to buy anything but standardized CACs. For them, the story goes, the only thing worse than a world in which CACs affected bond prices is a world in which CACs actually "became a source of competition" (Gray, 2003-2004).

We have re-told these stories in a somewhat stylized fashion. Put simply, the story of how CACs originated and evolved is a story of a mistake compounded by years of rote copying. Lawyers in New York and London supposedly imported corporate drafting conventions into sovereign bonds, either without bothering to read the forms they copied or because they were ignorant of the different legal regimes applicable to corporate and sovereign borrowers. These different drafting conventions persisted until the Official Sector helped lawyers to understand that the unanimity requirement made no sense for sovereign issuers. None of the stories so much as hint that the market valued these different drafting conventions differently. Nor do the stories suggest that the move away from unanimity in New York-law bonds created any space for innovation or competition. Instead, the stories imply that the move simply freed lawyers to copy a different set of forms - presumably those based on English law.

Figure 1 depicts what bond contracts would look like if this stylized story were true. It suggests that bonds governed by New York law incorporated the unanimity requirement sometime after the enactment of the Trust Indenture Act in 1939, while English-law bonds incorporated CACs at some earlier date, when lawyers first copied terms from corporate bonds. Figure 1 also shows the post-2003 convergence, when New York- and English-style drafting conventions merged. In the next section, we demonstrate that this story does not begin to capture actual drafting practices. We also consider some slightly more nuanced, though also inaccurate, stories about sovereign bonds. As we shall see, all posit a degree of standardization - and thus a lack of innovation - that simply does not map onto the contracts themselves. 
Figure 1

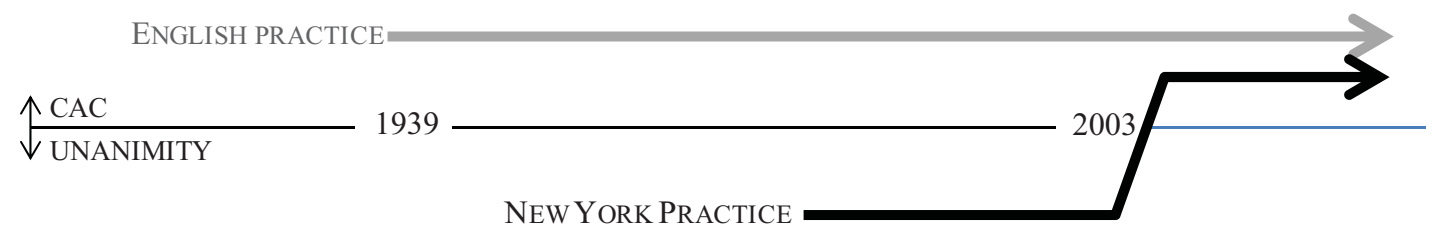

\section{Messy ReAlity: A StORY OF VARIANCE AND (MAYbe?) INNOVATION}

In this section, we contrast the stories against a dataset of sovereign bond contracts. The dataset consists of over 1300 contracts and disclosure documents for sovereign bonds issued between 1823-2010. To our knowledge, this is the most extensive and comprehensive available dataset of sovereign bond contracts. We provide details about the dataset in Weidemaier, Scott, and Gulati (2011).

\section{Pre-2003: The origins of separate English and New York drafting conventions}

The stories generate at least two predictions about the origin of the different drafting conventions under New York and English law. One is that majority amendment clauses have appeared in English-law sovereign bonds for over 100 years (Liu, 2002). There were many sovereign issuances in the 19th and early 20th centuries, and the majority amendment clause was available to be copied from English corporate forms by the 1870s (Buchheit \& Gulati, 2002). A second prediction is that sovereign bonds governed by New York law began to require unanimous assent to modify payment terms not long after the 1939 enactment of the TIA. The sovereign bond markets were not active in the ensuing decades, but there were issuances, and these could have copied the unanimity requirement from corporate documents.

Our dataset, however, supports neither prediction. The earliest CACs that we have found appeared simultaneously in London and New York in a 1922 Czechoslovakian bond issuance. 
These clauses allowed holders of a majority of the outstanding bonds to approve "any proposal" by the issuer - language seemingly broad enough to include a restructuring proposal. ${ }^{3}$ With that exception, however, none of the bonds issued before 1976 specified the vote required to amend payment terms, or for that matter any other terms. By remaining silent on the subject, these bonds effectively required that bondholders unanimously agree to any change. This was true of both New York and English-law bonds, meaning that sovereign bonds issued under English law did not conform to corporate drafting conventions that prevailed at the time. Our data suggest that amendment terms first began to appear in the mid-1970s but gained acceptance only slowly.

A relatively sudden shift begins in the mid-1980s. Up to that point, few bonds had addressed whether and how bondholders could amend bond terms. Beginning around 1985, a significant portion of the bonds began explicitly to address this subject and did so in a manner that was largely, but not completely, consistent with corporate drafting practices. Thus, most English-law bonds adopted terms that allowed a supermajority of bondholders to amend payment terms at a meeting of the bondholders. And most New York-law bonds adopted terms that allowed a majority of bondholders to amend some terms but explicitly required unanimous assent to modify payment-related terms.

The pre-2003 difference between New York and English drafting conventions is thus of recent vintage. The unanimity requirement in New York, moreover, did not result from lawyers blindly copying corporate bonds in the wake of the 1939 enactment of the Trust Indenture Act.

\footnotetext{
${ }^{3}$ We cannot identify exactly why the bonds included CACs, but the impetus may have come from the Financial Committee of the League of Nations, which was involved in arranging reconstruction loans to some European borrowers. The loan documents underlying the Czech bonds, for example, include a provision allowing the Financial Committee of the League to represent the bondholders if the government did not fulfill its obligations under the contract, and we doubt such a provision would have been included if League officials were not involved in shaping loan terms.
} 
In our sample, the first New York-law bond to adopt an explicit unanimity requirement was issued in 1981, over forty years after the passage of the TIA. Nor do English-law bonds reveal a long-standing practice of copying from corporate bonds. English-law sovereign and corporate bonds observed different drafting conventions until the mid-1980s.

Our data do not explain why these different drafting conventions emerged or why sovereign bonds began to adopt explicit modification provisions in the 1980s. A summary of the history of these markets may help provide some context for this shift. Although sovereign bond markets were robust throughout the 19th and early 20th centuries, a wave of Depression-era defaults dramatically reduced this form of sovereign lending. Sovereigns continued to issue bonds after World War II, but for several decades sovereign lending was dominated by multilateral lenders such as the World Bank or by commercial banks. The bond markets did not begin to revive in earnest until the late-1980s (Gelpern \& Gulati, 2008), which is around the time the different New York and English drafting conventions emerged. Thus, our data is consistent with a story of copying spurred by the revival of the sovereign bond markets. Perhaps lawyers at the time, suddenly pressed to do a large volume of sovereign bond transactions, borrowed some terms from corporate bonds issued under the relevant legal regime (Ahdieh, 2004; Eichengreen, 2003; Buchheit \& Gulati, 2002). But even if this story is true, it hardly follows that lawyers blindly or unthinkingly copied corporate bond documents.

To the contrary, there are other (we think, plausible) explanations why different conventions might have emerged in London and New York. One possibility is that investors already were familiar with the different drafting conventions for New York and English-law corporate bonds, and lawyers did not want to adopt unfamiliar practices for their increasing volume of sovereign issuances. A second possibility is that some investors preferred bonds that 
included terms that made restructuring more difficult. Financial institutions within the United States, for example, arguably had been more seriously affected by a wave of sovereign defaults that immediately preceded the adoption of amendment terms in the 1980s. These institutions may have been averse to the risk of default and may have preferred sovereign bonds that were relatively hard to restructure. Perhaps bonds issued under New York law attempted to satisfy this preference by requiring unanimous assent to any proposed restructuring. The different drafting conventions also may have resulted from different investor bases. There is some reason to believe that institutional investors dominated the New York market for sovereign bonds, whereas dispersed retail investors played a larger role in European markets. Because large institutional investors can more easily coordinate their response to a sovereign default than can a group of dispersed and small retail investors, there may have been less need for majority amendment terms in the New York market.

The point is that it is entirely possible that the different drafting conventions emerged in response to market demand and reflect different functional approaches to sovereign lending. We raise this as possibility, not fact, since the data do not rule out the blind copying story. It is striking, however, that lawyers choose to describe their work in terms that make lawyers seem ineffective or outright incompetent when there are equally plausible, and more flattering, characterizations available. Simply put, if the lawyers had explained that the different drafting conventions existed for a reason, we would have been inclined to agree, and nothing in our data would suggest otherwise. Yet time after time, lawyers explain sovereign bond contracts as the product of a rote and essentially unthinking copying process. ${ }^{4}$

\footnotetext{
${ }^{4}$ We should note that in no instance did any lawyer explicitly acknowledge engaging in blind copying. The stories purport to describe general practices in the industry. At least implicitly, however, the stories implicate all lawyers.
} 
So what caused the shift in 2003, when sovereign bonds governed by New York law finally moved away from the TIA model? This a complex question explored in detail in Gelpern \& Gulati (2006). For present purposes, what matters is that the stories often attribute the switch to the Official Sector's successful effort to disabuse issuers and their lawyers of the errant but long-standing belief that the TIA applied to sovereign bonds. We cannot disprove that sovereign issuers and their advisors held this belief, but we think it exceedingly unlikely. For one thing, the statute explicitly exempts from its scope "any note, bond, debenture, or evidence of indebtedness issued or guaranteed by a foreign government" (15 U.S.C. $77 \mathrm{ddd}(\mathrm{a})(6))$. We do not think it takes a $\$ 1000$-an-hour lawyer to understand what this means. For another, while sovereign debt lawyers readily attribute to others the mistaken belief that the TIA applied to sovereign bonds, we have yet to meet the lawyer who professes to have held this belief themselves.

\section{Variance (and innovation?) after 2003}

Stories of copying extend into the post-2003 era. The simplest story is that, when New York-law bonds began to adopt CACs, they simply borrowed the English model. If this version of the story were true, then the amendment provisions in New York and English-law bonds would look alike after 2003. Other versions of the story allow for some continuing differences. For example, bonds governed by New York law sometimes are described as conforming to a model promulgated by the G-10 Working Group on Contractual Clauses, an eminent group of lawyers who drafted model clauses at the behest of governments comprising the Group of Ten (Galvis \& Saad 2004, 2005). ${ }^{5}$ Likewise, bonds governed by English law sometimes are described as following a model clause promulgated by the International Capital Market Association

\footnotetext{
${ }^{5}$ The report and model clauses are available at http://www.bis.org/publ/gten08.pdf (Group of Ten, 2002).
} 
(ICMA), an industry trade group (Yianni \& Malek, 2010). ${ }^{6}$ But even these more nuanced stories tend to assume a high degree of standardization within the New York and English markets.

Our point is not that the lawyers deny the existence of variation in sovereign bonds; they do not (Koch, 2004; Richards, 2010). Rather, it is that sovereign debt lawyers emphasize standardization and, when they do acknowledge variation, they almost never take credit for it. For example, in two separate studies Gelpern and Gulati (2006) and Scott and Gulati (2011) interviewed lawyers they knew to be directly responsible for recent innovations in sovereign bond contracts. Time and again, the lawyers declined to characterize their work as creative or innovative. In the same vein, stories about CACs inevitably explain contract variance by attributing it to a mistake or to some authoritative external source: a statute (the TIA), a government-sanctioned drafting committee (the G-10 standard) or an important industry group (the ICMA standard). The stories do not attribute variance to lawyer ingenuity or competition.

Our data from the post-2003 era, however, reveal variation that is difficult to attribute to mistakes or to thoughtless adoption of model clauses. Beginning with bonds governed by New York law, our data reveal what at first appears to be a sudden shift from one standard to another. Before 2003, the vast majority of New York-law bonds required unanimous approval for any change to payment-related terms. After Mexico's 2003 adoption, the vast majority of New Yorklaw bonds have included modification clauses permitting changes to payment-related terms with the approval of the holders of at least 75 percent in aggregate principal amount of outstanding bonds.

Figure 2 depicts this shift by focusing on one variable: the minimum possible vote needed to amend payment-related terms. ${ }^{7}$ To understand the figure, bear in mind that a number of factors

\footnotetext{
6 The clause is available at http://www.icmagroup.org/ICMAGroup/files/3c/3cc80d90-da994562-8ef2-f604a8e5963e.PDF (International Primary Market Association, 2004).
} 
potentially influence the required vote. The most obvious is the voting threshold itself - here, 75 percent. But there are other important factors. For example, assume that a bond contract permits or requires the vote to occur at a meeting. The loan documents will specify the quorum for that meeting (typically 75 percent) and also may specify a lower quorum (say, 25 percent) for any postponed meeting. Now assume the modification clause requires the approval of "holders of 75 percent in aggregate principal amount of outstanding bonds represented at the meeting." This is the standard English-law CAC before 2003, and it in theory allows restructuring with the approval of holders of only 18.75 percent in aggregate principal amount of the outstanding bonds. ${ }^{8}$ A different (and purely hypothetical) bond might explicitly require the approval of "holders of 18.75 percent of aggregate principal amount of outstanding bonds," whether approval was solicited at a meeting or in writing. This bond, too, would permit amendment upon a favorable vote by holders of 18.75 percent of the debt. ${ }^{9}$

For simplicity, Figure 2 collapses these potential differences and reports only the minimum possible vote sufficient to modify payment terms. Before 2003, a handful of New York-law bonds - all issued by the same country - adopted the English model, and another handful permitted amendment with the approval of a 75 percent supermajority. But the vast majority required unanimous approval. After 2003, the vast majority permit amendment with the approval of a 75 percent supermajority.

\footnotetext{
${ }^{7}$ The figure only includes bonds that address the subject of modification.

${ }^{8}$ This would be the voting threshold at a postponed meeting with a 25 percent quorum $(.75 \times .25$ $=.1875)$.

${ }^{9}$ The previous example, by contrast, would permit amendment with a vote of 18.75 percent, but only in one limited scenario: a postponed meeting. Other scenarios would require a higher vote.
} 


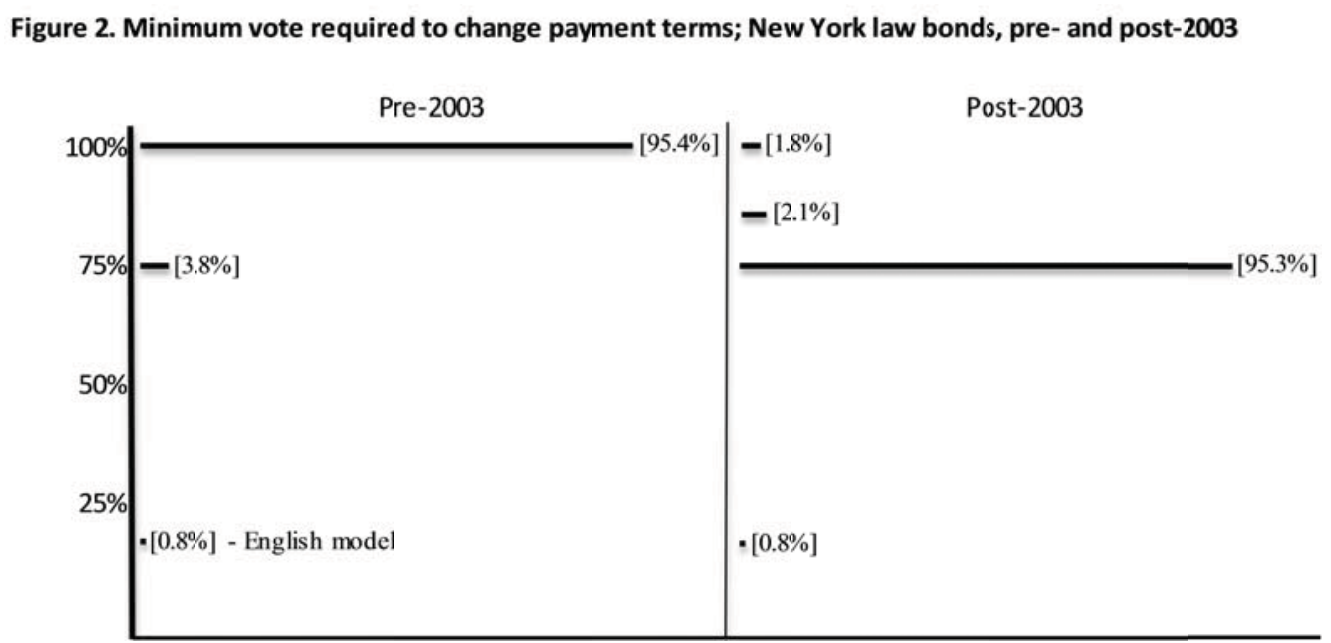

Figure 2 makes clear that the 2003 switch from unanimity to collective action in New York was not modeled on English forms. As noted above, bonds governed by English law typically allowed restructuring with a vote as low as 18.75 percent ( 75 percent of aggregate principal amount of bonds represented at a postponed meeting with a 25 percent quorum). Bonds issued under New York law, by contrast, typically do not contemplate a meeting and require the approval of holders of at least 75 percent in aggregate principal amount of the bonds.

At first glance, Figure 2 seems consistent with a story of blind copying in two respects. First, the fact that the vast majority of issuances adopt the same voting threshold is consistent with a story in which later issuers simply adopt forms used by earlier ones. Second, the 75 percent voting threshold matches that recommended by the G-10 working group in its model clause. After noting concerns that the English model made restructuring too easy and thus too tempting for sovereign borrowers, the working group adopted 75 percent as a "reasonable threshold" (Group of Ten Report, 2002).

There is, however, additional variance in the New York-law bonds that undermines these copying stories. The G-10 working group, for example, recommended that sovereign bonds appoint a trustee or other permanent representative of bondholder interests. But only a small 
minority (10.8\%) of post-2003 issuances adopts the trust structure, and only two issuers of New York-law bonds explicitly provide for the appointment of a committee to represent bondholders, even on a temporary and limited basis. The G-10 working group, moreover, recommended that all bonds issued under New York law contain provisions requiring a 25 percent vote to accelerate the loan after a default. Despite this recommendation, there remains significant variance in New York. Nineteen issuers have continued to allow individual bondholders to accelerate their loans, and even those issuers who have limited the right to accelerate often depart from the G-10's recommended 25 percent threshold. ${ }^{10}$

But the variance in bonds governed by New York law is trivial compared with the post2003 variance under English law. In fact, it is as if the switch from unanimity to majority amendment terms in New York created a space in which issuers of English-law bonds could experiment. To put this in context, experimentation is not exactly the norm with boilerplate sovereign bond contracts. Figure 3 depicts a rather dramatic change in English-law bonds, again focusing on the minimum possible vote to change payment terms. Recall that, before 2003, holders of as little as 18.75 percent of the aggregate principal amount of outstanding bonds could vote to modify payment terms. Ninety-three percent of pre-2003 English-law issuances conformed to this standard. After 2003, English-law bonds have adopted a dizzying array of approaches. Nearly 30 percent adhere to the former English standard. Approximately one-third have adopted the New York model and now require a vote of at least 75 percent to amend payment terms. The rest adopt a range of voting thresholds that do not match any bonds

\footnotetext{
${ }^{10}$ For example, four issuers allow acceleration on a vote of holders of $10 \%$ of the aggregate principal amount of outstanding bonds, while two more allow acceleration after a 33 percent vote.
} 
previously-issued under New York or English law and that do not conform to either the G-10 or ICMA models.

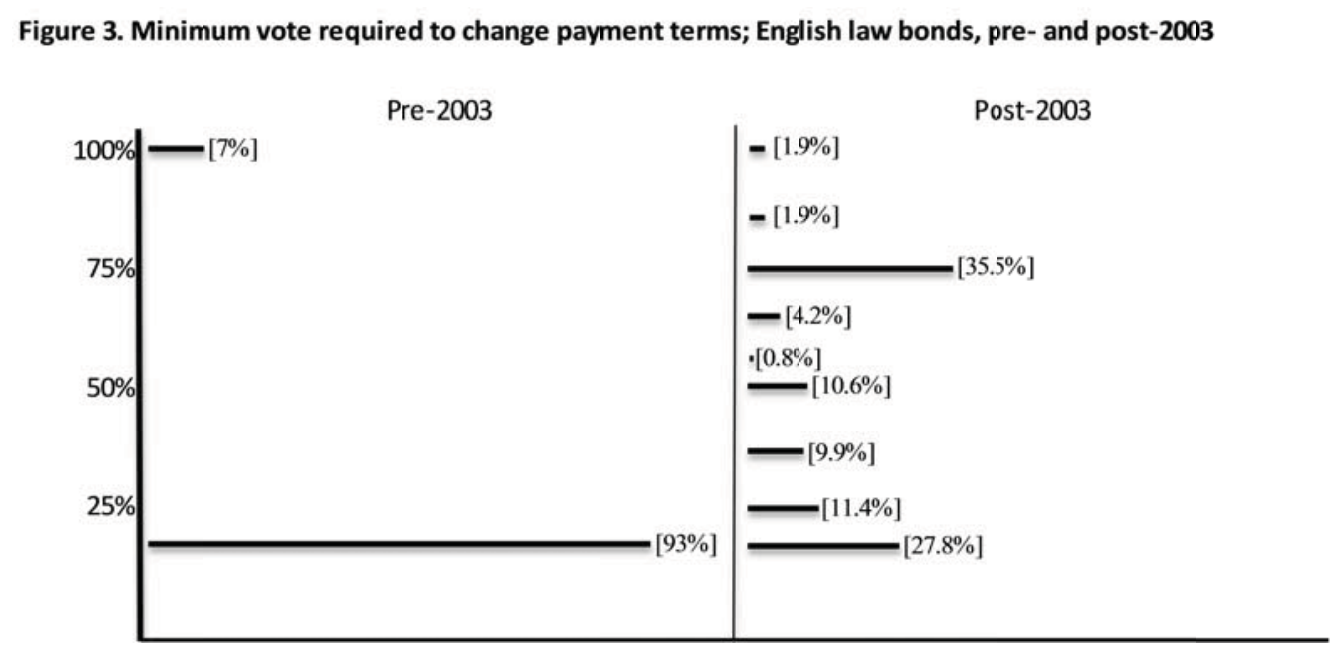

This variance does not square with any version of the copying story. And there is additional variance, not fully captured by Figure 3, across a range of collective action terms. A minority of post-2003 issuances, for example, have selectively adopted some aspects of the ICMA model clause, such as the term permitting bondholders to appoint a committee to represent them in negotiations with the issuer (5.9\% versus $0 \%$ pre-2003). A much larger percentage have adopted terms preventing individual bondholders from accelerating their loans another ICMA recommendation (68\% versus 48\% pre-2003). In addition, some English-law issuances $(14.6 \%)$ have introduced another ICMA recommendation: a new term requiring unanimous approval to change a select few terms unrelated to the issuer's payment obligations, such as choice of law clauses. In each of these cases, the issuer appears to have selectively adopted parts of the ICMA model clause, sometimes pairing these borrowed terms with completely new provisions. One issuer, for example, adopted two of the ICMA recommendations but permitted amendment to payment terms upon a vote of only 37.5 percent of the aggregate principal amount of outstanding bonds - an apparently novel voting threshold. 
Thus, the picture that emerges from actual contracting practices is far more complex than the lawyer stories imply. At a minimum, our data suggest that some under-the-radar innovation persists despite relatively uniform drafting practices in post-2003 New York-law bonds. After 2003, moreover, English-law bonds appear to have entered a period of active foment that has not yet subsided. We cannot prove that these changes resulted from deliberate innovation by lawyers, but they are certainly consistent with that story. So we return, once again, to the question why lawyers would portray their own work in such unflattering terms. Why would such an elite group of lawyers be so fond of stories that portray them as ineffective and impotent market actors, when the data is consistent with a much more flattering story?

\section{IMPLICATIONS}

Sovereign debt lawyers have been talking about CACs for at least a decade. In doing so, they also have been talking about themselves - communicating information about their work and their main claim to expertise: designing sophisticated contracts for complex transactions. Why would they speak in such negative terms? We do not believe there is a straightforward answer to this question, but we offer some tentative suggestions.

\section{They Don't Think; They Just Do}

In at least one respect, it is not surprising that lawyers tell inaccurate stories about contracts. As some of our economist colleagues have pointed out, some CEOs might deny that their companies raise or lower prices in response to changes in supply and demand. Instead, they might claim that their prices are driven by other concerns, such as the desire to produce the best quality product. (Henry Ford famously claimed he only wanted to provide the public with affordable cars, even while producing spectacular profits.) To take another example, pool players employ the laws of physics quite nicely, even if they cannot describe them. So perhaps we should not expect sovereign debt lawyers to wrap their own stories in some broader market 
narrative - explaining, say, that bond terms evolve in response to market demand for more or less protection against restructuring. After all, they are busy and may not have time to formulate cogent explanations for their work. Perhaps they just do the work.

We are inclined to agree with this sentiment, but we do not think it fully responds to the questions raised by the stories. It may be no surprise that lawyers do not know the origin of boilerplate terms or the reasons why those terms have evolved over time. After all, the same boilerplate form may persist for generations of lawyers, gathering contract terms like "barnacles" along the way (Wood 2009). It is more surprising, however, that lawyers care about origins enough to devise stories to explain the provenance of contract terms (Weidemaier, Scott \& Gulati 2011). And it is more surprising still that such an elite group of lawyers has devised such an unflattering set of stories.

The CEOs posited by our economist colleagues describe their actions in selfcongratulatory terms - as motivated by concern for the customer, desire to produce the best product, etc. But our lawyers tell stories that make them look bad. They describe sovereign debt lawyers as largely uninterested in the quality of their contracts and as engaged primarily in rote copying. True, the stories tend to blame other lawyers for the most egregious errors, such as mistakenly believing the TIA applies to sovereign bonds. But the stories implicate all lawyers in the mindless copying that supposedly characterizes sovereign debt work. Because our contracts data suggests that something other than mindless copying is going on, we think the larger puzzle is why these elite lawyers do not seem to embrace the philosophy of the market in which they plainly operate.

\section{Back to Polanyi}

A better explanation might attempt to situate these stories in the broader context of sovereign debt legal work. If the stories were accurate they would paint a picture of seemingly 
irrational behavior: sophisticated transactional lawyers copying suboptimal forms rather than designing contracts that would maximize value for their clients. Adopting Polanyi's concept of "embeddedness," sociologist Mark Granovetter has observed that such seemingly irrational behavior "may be quite sensible when situational constraints" are taken into account (Granovetter, 1985, p. 506). ${ }^{11}$ In the context of sovereign lending transactions, situational constraints include time pressure, lawyers' natural reluctance to change contract boilerplate, and concern on the part of bankers, investors, and issuers over the pricing implications of new contract language. Given these constraints, blind copying might be a perfectly rational strategy.

The problem, of course, is that the contracts data suggest that lawyers are not engaged in blind copying; this is just how they describe sovereign debt legal work. But here too, situational constraints may explain why lawyers inaccurately describe their work in these terms. It is true that the stories we have recounted paint an unflattering picture of lawyers. That unflattering picture, however, may serve a purpose. We suspect that most participants in the sovereign debt markets assume that bond contracts are standardized, at least in material respects. To an extent, that assumption is self-serving: bond contracts are lengthy, and what investor wants to scrutinize dozens of pages of boilerplate looking for slight changes in wording that might distinguish two bonds?

Sovereign debt lawyers may be accustomed to encouraging this view, even if doing so causes some insult to their professional status. This is because - paradoxically - the assumption of standardization may create space in which lawyers can actually do their work. We have little doubt that sovereign debt lawyers see themselves as elite practitioners whose status derives, at

${ }^{11}$ Granovetter's extension of Polanyi's concept of embeddedness provoked a fair amount of discussion (Krippner et al. 2004). That discussion is not relevant to our purposes, so we pass it by. 
least in part, from their ability to design contracts. Yet sovereign lending transactions are driven by bankers and finance officials who are likely to resist making changes to contract boilerplate. Perhaps by cultivating stories of standardization, lawyers deflect attention from the fact that they do make frequent, albeit modest, changes to contract templates. Likewise, stories that (wrongly) attribute changes to some approved source - such as model clauses promulgated by ICMA or the G-10 drafting committee - suggest that some external authority has vetted the change to assure that market participants will not react unfavorably.

We are speculating, of course. Our aim is to find some rational explanation for why even senior sovereign debt lawyers routinely fail to characterize themselves as potent market actors (Weidemaier, Scott \& Gulati 2011). We are skeptical that these lawyers are content to run the copy machine - or that their clients are content to pay $\$ 1000$ or more an hour for that service and we think our contracts data shows that a good deal more is going on. Lawyers are constrained, it is true, and we think it fair to say that most innovation in sovereign debt contracts occurs at the margin. But innovation occurs nonetheless. It is at least possible that the stories create some space for this to occur.

\section{Conclusion: CACs in the Eurozone}

We write this in July 2011, and CACs are back in the news. Senior Eurozone officials have stated that they want all Eurozone sovereigns to adopt identical CACs in future issuances, and multiple drafting committees are busy designing the template for the new clauses (Buchheit \& Gulati, 2011). To date, this project has drawn no serious objections from sovereign debt lawyers. In other contexts, the lack of resistance would be unusual. After all, the politicians are proposing that governments, not lawyers and not markets, should fix contract terms.

In the context of sovereign lending, the lack of resistance is less surprising. Judging by their stories, sovereign debt lawyers do not characterize their own work in market terms. Instead, 
they emphasize that they mainly copy old forms, and they attribute contract change to the beneficent intervention of outside actors, such as public officials who explain that sovereigns need not observe statutory requirements applicable only to corporate issuers, or working groups that design new model clauses for lawyers to copy instead of their existing forms. Yet these stories are hard to square with the contracts themselves, which appear to reveal a good deal of innovation. It remains to be seen whether a new, government-created "model" will suppress that innovation for long.

\section{Bibliography}

Bauman, R. (1986). Story, performance, and event: Contextual studies of oral narrative. Cambridge: Cambridge University Press.

Bratton, W. W. (2004). Pari Passu and a distressed sovereign's rational choices. Emory Law Journal, 53, 823-68.

Briggs, Charles L. (1996). Introduction. In C. Briggs, (Ed.), Disorderly discourse: Narrative, conflict, and inequality (pp. 3-40). Oxford: Oxford University Press.

Buchheit, L. C. \& Gulati, M. (2011). Drafting a Model Collective Action Clause for Eurozone Sovereign Bonds. Capital Markets Law Journal (forthcoming).

Buchheit, L. C. \& Gulati, M. (2010). How to restructure Greek debt. Retrieved from http://papers.ssrn.com/sol3/papers.cfm?abstract_id=1603304.

Buchheit, L. C. \& Gulati, M. (2002). Sovereign bonds and the collective will. Emory Law Journal, 51, 1317-1364.

Eichengreen, B. (2003). Restructuring sovereign debt. Journal of Economic Perspectives, 7, 7598.

Eichengreen, B. \& Portes R. (1995). Crisis? What crisis? Orderly workouts for sovereign debtors. London: Centre for Economic Policy Research.

Eichengreen, B. \& Mody A. (2000a). Would collective action clauses raise borrowing costs? An update and additional results. World Bank Policy Research Paper Working Series, No. 2363.

Eichengreen, B. \& Mody A. (2000b). Would collective action clauses raise borrowing costs? NBER Working Paper Series, No. 7458.

Engle, D. M. (1993). Origin myths: Narratives of authority, resistance, disability, and law. Law \& Society Review, 27, 785-826. 
Eurogroup. (2010a). Memo/10/636: European stability mechanism (ESM)- Q\&A [Press release]. Retrieved from http://europa.eu/rapid/pressReleasesAction.do?reference=MEMO/10/636.

Eurogroup. (2010b). Statement by the Eurogroup of November 28, 2010. Retrieved from http://www.consilium.europa.eu/uedocs/cms data/docs/pressdata/en/ecofin/118050.pdf.

Galvis, S. \& Saad, A. (2004). Collective action clauses: Recent progress and challenges. Georgetown Journal of International Law, 35, 713-729.

Galvis, S. \& Saad, A. (2005). Sovereign exchange offers in 2010. Chicago Journal of International Law, 6, 219-229.

Gelpern, A. \& Gulati, M. (2006). Public symbol in private contract: A case study. Washington University Law Review, 84, 1627-1715.

Gelpern, A. \& Gulati, M. (2008). Innovation after the revolution: Foreign sovereign bond contracts since 2003. Capital Markets Law Journal, 4, 85-103.

Granovetter, M. (1985). Economic action and social structure: The problem of embeddedness. American Journal of Sociology, 91, 481-510.

Gray, R. B. (2003a). Collective action clauses: Remarks prepared for delivery at UNCTAD Fourth Inter-Regional Debt Management Conference in Geneva. Retrieved from http://www.icmagroup.org.

Gray, R. B. (2004). Collective action clauses: Theory and practice. Georgetown Journal of International Law, 35, 693-711.

Gray, R. B. (2003b). Crisis resolution: A market-based approach. In S. Griffith-Jones, A. Bhattacharya, \& A. Antoniou (Eds.), Enhancing private capital flows to developing countries (pp. 33-38). London: Commonwealth Secretariat.

Group of 10. (2002). Report of the G-10 Working Group on Contractual Clauses. Retrieved from http://www.bis.org/publ/gten08.pdf.

Gugiatti, M. \& Richards, A. (2004). The use of collective action clauses in New York law bonds of sovereign borrowers. Georgetown Journal of International Law, 35, 815-835.

Gulati, M. \& Scott, R. (2011). The three and a half minute transaction: Boilerplate and the limits of contract design. Unpublished manuscript.

International Primary Market Association. (2004). Standard collective action clauses for the terms and conditions of sovereign notes: English law, fiscal agent structure. Retrieved from http://www.icmagroup.org/ICMAGroup/files/3c/3cc80d90-da99-4562-8ef2-f604a8e5963e.PDF.

Koch, E. B. (2004). Collective action clauses: The way forward. Georgetown Journal of International Law, 35, 665-91.

Krippner, G., Granovetter, M., Block, F., Biggart, N. Beamish, T., Hsing, Y., Hart, G., Arrighi, G., Mendell, M., . . \& \& O'Riain, S. (2004). Polanyi Symposium: A conversation on embeddedness. Socio-Economic Review, 2, 109-135. 
Mather, L., McEwin, C., \& Maiman, R. (2001). Divorce lawyers at work: Varieties of professionalism in practice. Oxford: Oxford University Press.

Oakley, D. (2011). Bond dealers skeptical about Eurozone plans. Financial Times. Retrieved from http://www.ft.com/cms/s/0/d1d45e36-5a33-11e0-86d3-00144feab49a.html\#axzz.

O’Barr, W. M. \& Conley, J. M. (1992a). Fortune and folly: The wealth and power of institutional investing. Homewood, IL: Business One Irwin.

Olivares-Caminal, R. (2009). To rank Pari Passu or not to rank Pari Passu: That is the question in sovereign bonds after the latest episode of the Argentine saga. Law and Business Review of the Americas, 15, 745-779.

Quarles, R. (2010). Herding cats: Collective action clauses in sovereign debt - The genesis of the project to change market practice in 2001 through 2003. Law \& Contemporary Problems, 73, 29-38.

Richards, M. B. (2010). The Republic of Congo's debt restructuring: Are sovereign creditors getting their voice back? Law and Contemporary Problems, 73, 273-299.

Roe, M. J. (1987). The voting prohibition in bond workouts. Yale Law Journal, 97, 232-279.

Roubini, N. \& Setser B. (2004). Bailouts or bail-ins? Responding to financial crises in emerging economies. Washington, DC: Institute for International Economics.

Sachs, J. (1984). Theoretical issues in international borrowing. Princeton Studies in International Finance. Princeton: Princeton University Press, July, 54.

Skeel, D. A., Jr. (2003). Can majority voting provisions do it all? Emory Law Journal, 52, 417426.

Skeel, D. A., Jr. (2001). Debt's dominion: A history of bankruptcy law in America. Princeton: Princeton University Press.

Stiglitz, J. E. (2001). Foreword to The Great Transformation (pp. vii-xviii). Boston: Beacon Press.

Weidemaier, M. (2009). Disputing Boilerplate. Temple Law Review, 82, 1-54.

Weidemaier, M., Scott R. R., \& Gulati, M. (2011). Contracts, origin myths, and the hunt for Pari Passu. Law and Social Inquiry (forthcoming).

Weinschelbaum, F. \& Wynne, J. (2005). Renegotiation, collective action clauses and sovereign debt markets. Journal of International Economics, 67, 47-72.

Wood, P. R. (2009). Life after Lehman: Allen \& Overy analysis of changes in market practice. London: Allen \& Overy.

Yianni, A. \& Malek, L. (2010). Seychelles debt restructuring: Restoring the viability of public finances. Journal of International Banking Law and Regulation, 25, 330-336. 